\title{
Comparative study of larvicidal activity of commercial essential oils from aromatic rosemary, vanilla, and spearmint against the mosquito Aedes aegypti
}

\author{
SEDTHAPONG LAOJUN, TANAWAT CHAIPHONGPACHARA \\ Department of Public Health and Health Promotion, College of Allied Health Sciences, Suan Sunandha Rajabhat University. Samut Songkhram 75000, \\ Thailand. "email: tanawat.ch@ssru.ac.th
}

Manuscript received: 26 March 2020. Revision accepted: 8 May 2020.

\begin{abstract}
Laojun S, Chaiphongpachara T. 2020. Comparative study of larvicidal activity of commercial essential oils from aromatic rosemary, vanilla, and spearmint against the mosquito Aedes aegypti. Biodiversitas 21: 2383-2389. Dengue fever is a dangerous mosquito-borne viral disease of humans. This disease is caused by dengue virus, a member of the genus Flavivirus of the family Flaviviridae. The Aedes aegypti mosquito is a principal vector for this virus. To control Ae. aegypti populations, there is extensive focus on larval eradication, because breeding sites are often close to human populations, especially man-made containers. The objective of this research was to evaluate the efficacy of commercial essential oils from rosemary (Rosmarinus officinalis), vanilla (Vanilla planifolia), and spearmint (Mentha spicata) with regard to larvicidal activity against Ae. aegypti larvae after 24 and 48-hours of exposure in the laboratory. The results showed highly efficacious larvicidal activity, with median lethal doses (LC50) of 0.23, 0.10, and 0.12 ppm after 24-hour exposure to commercial rosemary, vanilla, and spearmint oil, respectively. The results of this study will be useful for the control of a common dengue vector and may replace the use of pesticides that may have broad environmental impacts.
\end{abstract}

Keywords: Aedes aegypti, essential oils, larvicidal activity, vector control, public health

\section{INTRODUCTION}

Mosquitoes are small flying insects in the family Culicidae. Several subfamilies exist with many species. Of particular interest are species in the subfamilies Anophelinae and Culicinae, which include mosquitoes in the genera Aedes, Anopheles, and Culex. Mosquitoes in these genera are vectors of human pathogens, including viruses (such as yellow fever virus, West Nile virus, Japanese encephalitis virus, dengue virus, chikungunya virus, and Zika virus), protozoa (such as Plasmodium parasites), and nematodes (such as Wuchereria bancrofti, Brugia malayi, and Brugia timori; Bond et al. 2014; Derua et al. 2017; Pratiwi et al. 2019; Souza-Neto et al. 2018; Tandina et al. 2018). Immature stages of mosquitoes, including larvae and pupae, live in the water before emerging from it as adults. Adult male and female mosquitoes feed on nectar from flowers and plant juices. However, females require blood to furnish nutrients for developing eggs (Service 2008). This requirement facilitates transmission of dangerous pathogens to humans and other animals when females bite to draw blood. Dengue fever is one dangerous mosquito-borne viral disease of humans. The disease is caused by dengue virus, a member of the genus Flavivirus of the family Flaviviridae. The virus occurs throughout the world, especially in tropical and sub-tropical regions.

The female Aedes aegypti mosquito is a principal vector (also called a primary vector) of dengue (Hasan et al. 2016). Aedes aegypti, the yellow fever mosquito, belongs to the subgenus Stegomyia within the subfamily Culicinae
(Harbach 2019). Aedes species originated in Africa but are presently distributed throughout the world due to humanbased transportation (Eskildsen et al. 2018). On the other hand, Aedes albopictus, the "Asian tiger mosquito," is a secondary vector of dengue and originated in Southeast Asia (Goubert et al. 2016). The World Health Organization (WHO) reports that dengue fever is the largest human disease burden, with an estimated 390 million people in 128 countries infected every year (WHO 2020).

Reducing the number of Aedes mosquitoes is recognized as an effective means to reduce risks and control the outbreak of dengue fever (Ma et al. 2016; Weeratunga et al. 2016). For controlling Ae. aegypti populations, there is an intense focus on larvae eradication, because breeding sites are often close to human populations, especially man-made containers (Chaiphongpachara et al. 2018; Rohani et al. 2014). Currently, the insecticide that is widely used to control Aedes mosquito larvae is temephos (original trade name Abate), which is a non-systemic organophosphorus insecticide (George et al. 2015). However, dengue vector resistance to temephos has been reported in many countries (Hasmiwati and Supargiyono 2018; Hasmiwati et al. 2018), including Argentina (Albrieu et al. 2010), Brazil (Valle et al. 2019), Colombia (Grisales et al. 2013), Ecuador (Morales et al. 2019), and Guadeloupe and Saint Martin (Goindin et al. 2017). Therefore, other alternative products are needed to solve this problem. Synthetic chemical insecticides are highly effective for killing several insects, including mosquito vectors. However, these synthetic chemicals are not accepted by the community because they are highly toxic 
to humans and animals (Ndakidemi et al. 2016; Andila et al. 2018). In addition, these chemicals can accumulate in the environment (Nkya et al. 2013; Jayaraj et al. 2016). Natural products are alternative insecticides that are currently popular (Mossa et al. 2018). The advantage of natural products for mosquito control is elevated environmental safety and no toxicity to organisms (Govindarajan and Benelli 2016).

Essential oils are naturally occurring volatile substances extracted from plants (Geetha and Roy 2014; Utami 2016; Arifiyanto et al. 2017; Hasani et al. 2017). These oils are used for their anti-stress properties as well as aromatherapy (Ali et al. 2015). They are also major components of cosmeceuticals (Sarkic and Stappen 2018), and their use in medicine is currently of some interest (Ali et al. 2015). Volatile oils of some plants are used to treat skin diseases (Orchard and Van Vuuren 2017) and are also used as insect repellents or for insect control, e.g., for mosquitoes (Pavela 2015; Lee 2018). Essential oils are easy to obtain, commercially available, and represent sustainable plant products (Dhifi et al. 2016). Thus, practical applications for these oils have been repeatedly sought.

Rosmarinus officinalis (rosemary), Vanilla planifolia (vanilla), and Mentha spicata (spearmint) are plants grown partly to extract essential oils. The aromas of these oils are easily recognized by many people across the globe (de Sousa et al. 2015; Baqueiro-Peña and Guerrero-Beltrán 2017; Fiume et al. 2018). Previous studies have reported that rosemary, vanilla, and spearmint essential oils repel arthropods (Nerio et al. 2010; Koc et al. 2012; Francikowski et al. 2019). Rosemary and spearmint oils are also toxic to small insects, such as larvae of armyworms Pseudaletia unipuncta (Isman et al. 2008) and Culex quinquefasciatus (Susilowati 2018) for rosemary oil, and larvae of rice moth Corcyra cephalonica (Khani et al. 2012) for spearmint oil. V. planifolia shows antimicrobial activity against some pathogenic bacteria (Bilcu et al. 2014). It is unknown whether three essential oils be able to kill larvae of Ae. aegypti. Therefore, this study used commercial rosemary, vanilla, and spearmint essential oils and tested their larvicidal activity against Ae. aegypti in the laboratory. The results of this study will be useful for the control of a common dengue vector and may replace the use of pesticides that may have broad environmental impacts.

\section{MATERIALS AND METHODS}

\section{Commercial essential oils}

The three commercial aromatic essential oils including rosemary $(R$. officinalis), vanilla ( $V$. planifolia), and spearmint ( $M$. spicata) were purchased from Chemipan (Bangkok, Thailand). The product data indicate that all three natural oils are extracted by steam distillation from rosemary and vanilla flowers, and spearmint leaves. Oils were stored in amber glass bottles at room temperature (25$28^{\circ} \mathrm{C}$ ) and away from sunlight.

\section{Rearing of mosquito larvae}

Laboratory-reared Ae. aegypti larvae were procured from the Department of Medical Sciences, Ministry of Public Health, Bangkok, Thailand. Larval mosquitoes were sent to the laboratory of the College of Allied Health Sciences, Suan Sunandha Rajabhat University, Thailand, and reared in a plastic tray containing filtered water until the late third larval stage. Mashed dog biscuits were used as larval food. Laboratory conditions were controlled at 25$28^{\circ} \mathrm{C}, 70-80 \%$ relative humidity, with a 12 -hour light/12hour dark cycle.

\section{Larvicidal bioassay}

The larvicidal bioassay was modified from the WHO method (WHO 2005). Aromatic rosemary, vanilla, and spearmint essential oils were prepared and diluted with filtered water containing $1 \mathrm{~mL}$ of absolute methanol (solvent) at concentrations of $0.05,0.10,0.15,0.20,0.25$, and $0.30 \mathrm{ppm}$.

Twenty-five late third instar larvae were put into 250 $\mathrm{mL}$ beakers containing essential oil solutions. For the duration of testing, the larvae were not fed. For each concentration of the three oils, four replicates were used, for a total of 100 larvae for each oil and each concentration. Each oil and concentration test included a set of control larvae not exposed to essential oils. Twenty-four and 48 hours after treatment, larval mortality was recorded. Aedes aegypti larvae were considered dead when they did not move.

\section{Data analysis}

Probit analysis was applied to determine the concentrations required to kill 25, 50, and $90 \%$ of the larvae ( $\mathrm{LC}_{25}, \mathrm{LC}_{50}$, and $\mathrm{LC}_{90}$, respectively) 24-hours postexposure. Statistical analysis including probit analysis, 95\% confidence intervals, and chi-square test using LdP Line software (http://www.ehabsoft.com/ldpline/). Analysis of variance (ANOVA) followed by Duncan's multiple range test was used to compare larval mortality among groups (24 and 48 hours each concentration) using $\mathrm{R}$ software. The statistical significance was set at $p<.05$.

\section{RESULTS AND DISCUSSION}

\section{Results}

In the present study, commercial pure rosemary $(R$. officinalis), vanilla ( $V$. planifolia), and spearmint ( $M$. spicata) essential oils showed significant larvicidal activity against Ae. aegypti larvae (Table 1). Overall, there was $100 \%$ larval mortality for all plant oils at concentrations ranging from $0.05-0.30 \mathrm{ppm}$. Percent mortality increased with the essential oil concentrations (Table 1).

Larvicidal activities of three oils against Ae. aegypti larvae after 24 and 48 hours of exposure were analyzed using probit analysis. After 24-hour exposure, vanilla oil was most potent $\left(\mathrm{LC}_{25}=0.08 \mathrm{ppm}, \mathrm{LC}_{50}=0.10 \mathrm{ppm}\right.$, and $\left.\mathrm{LC}_{90}=0.15 \mathrm{ppm}\right)$, followed by spearmint oil $\left(\mathrm{LC}_{25}=0.11\right.$ ppm, $\mathrm{LC}_{50}=0.12 \mathrm{ppm}$, and $\left.\mathrm{LC}_{90}=0.16 \mathrm{ppm}\right)$ and rosemary oil $\left(\mathrm{LC}_{25}=0.18 \mathrm{ppm}, \mathrm{LC}_{50}=0.23 \mathrm{ppm}\right.$, and $\mathrm{LC}_{90}$ $=0.35 \mathrm{ppm})($ Table 2$)$. For the 48-hour exposure, vanilla 
oil again was most potent $\left(\mathrm{LC}_{25}=0.07 \mathrm{ppm}, \mathrm{LC}_{50}=0.08\right.$ ppm, and $\left.\mathrm{LC}_{90}=0.12 \mathrm{ppm}\right)$, followed by spearmint oil $(\mathrm{LC} 25=0.10 \mathrm{ppm}, \mathrm{LC} 50=0.12 \mathrm{ppm}$ and $\mathrm{LC} 90=0.15$ $\mathrm{ppm})$ and rosemary oil $\left(\mathrm{LC}_{25}=0.15 \mathrm{ppm}, \mathrm{LC}_{50}=0.21 \mathrm{ppm}\right.$ and $\left.\mathrm{LC}_{90}=0.41 \mathrm{ppm}\right)$.

There were statistically significant among the oils with regard to $\mathrm{LC}_{25}, \mathrm{LC}_{50}$, and $\mathrm{LC}_{90}$ values (Figures 1-3). The efficacy of larvicidal activity of commercial aromatic oils on Ae. aegypti between 24 and 48 hours of exposure was significantly different for rosemary and vanilla oils, but not for spearmint oil (Figures 2 and 3).

\section{Discussion}

The control of Aedes spp. larvae is an important key to reducing the mosquito vector population and decreasing the incidence of dengue fever (Barrera et al. 2018; Roiz et al. 2018; Chaiphongpachara et al. 2019). Essential oils are a group of natural products that may have important larvicidal properties that are useful for the control of mosquito larvae in man-made containers (Dias and Moraes 2014). Our data showed that all three commercial aromatic essential oils were highly efficacious against Ae. aegypti larvae in the laboratory: rosemary $\left(\mathrm{LC}_{50}=0.23 \mathrm{ppm}\right.$ at 24 hours), vanilla $\left(\mathrm{LC}_{50}=0.10 \mathrm{ppm}\right.$ at 24 hours $)$, and spearmint $\left(\mathrm{LC}_{50}=0.12 \mathrm{ppm}\right.$ at 24 hours $)$.

For the interpretation of natural product performance, Komalamisra et al. (2005) and Cheng et al. (2003) suggested that an $\mathrm{LC}_{50}<50 \mathrm{~mL} / \mathrm{L}(\mathrm{ppm})$ indicates high activity. The current results are consistent with previous reports on the $\mathrm{LC}_{50}$ of rosemary essential oil for mosquito larvae, including $C x$. quinquefasciatus $(30.60 \mu \mathrm{g} / \mathrm{mL})$, Culex tritaeniorhynchus $(115.38 \mu \mathrm{g} / \mathrm{mL})$, and Anopheles subpictus (64.50 $\mu \mathrm{g} / \mathrm{mL})$ (Mahmoud et al. 2019). Govindarajan et al. (2012) studied larvicidal activity of spearmint essential oil on mosquito vectors and estimated
$\mathrm{LC}_{50}$ values of $62.62 \mathrm{ppm}$ for $C x$. quinquefasciatus, 56.08 ppm for Ae. aegypti, and $49.71 \mathrm{ppm}$ for Anopheles stephensi. Vanilla essential oil has not previously been tested for larvicidal activity, but there were reports on antimicrobial activity against some human pathogenic bacteria (Bilcu et al. 2014).

In general, the biological activity of essential oils is related to their major constituents (Dias and Moraes 2014). The major constituents of three essential oils are 1,8cineole $(52.8 \%)$ for rosemary (El-Massry et al. 2008), aliphatic acids, and phenolic compounds for vanilla (PérezSilva et al. 2006), and carvone (48.60\%) for spearmint. These chemicals are all reportedly toxic to insects (Tripathi et al. 2003; Tripathi et al. 2009; Pavela 2015; Bullangpoti et al. 2018). From the statistical analysis, vanilla oil proved to be most potent, followed by spearmint and rosemary. This result is consistent with historical literature reviews that found at equivalent concentrations, rosemary essential oil is less toxic than spearmint essential oil (Dias and Moraes 2014).

The main strength of using commercially aromatic rosemary, vanilla, and spearmint essential oils all plantderived natural products to control Ae. aegypti in the community is their wide availability and relatively low cost. Usually, the habitat of immature Aedes mosquitoes is artificial containers with clean water that are located around houses (Getachew et al. 2015; Islam et al. 2019; Kahamba et al. 2020). The results from this study indicate that all three essential oils might be useful in the field to control dengue vector mosquitoes. However, successfully controlling Aedes species larvae will require strong cooperation of the people in the area (Achee et al. 2015; Chaiphongpachara and Moolrat 2017; Flores and O'Neill 2018).

Table 1. Mosquito larval mortality after exposure to three oils in each concentration

\begin{tabular}{ccccccc}
\hline \multirow{3}{*}{ Concentrations $(\mathbf{p p m})$} & \multicolumn{4}{c}{ \% Mortality (means \pm S.E.) after exposure to pure essential oils } \\
\cline { 2 - 6 } & \multicolumn{2}{c}{ Rosemary } & \multicolumn{2}{c}{ Vanilla } & \multicolumn{2}{c}{ Spearmint } \\
\cline { 2 - 7 } & $\mathbf{2 4}$ hours & $\mathbf{4 8}$ hours & $\mathbf{2 4}$ hours & $\mathbf{4 8}$ hours & $\mathbf{2 4}$ hours & $\mathbf{4 8}$ hours \\
\hline 0.05 & 0 & $3 \pm 1.91$ & 0 & $3 \pm 1.91$ & 0 & 0 \\
0.10 & 0 & $4 \pm 2.83$ & $55 \pm 7.72$ & $80 \pm 9.93$ & $14 \pm 6.83$ & $24 \pm 5.16$ \\
0.15 & 0 & $6 \pm 1.15$ & $92 \pm 1.63$ & $98 \pm 1.15$ & $87 \pm 1.91$ & $87 \pm 1.91$ \\
0.20 & $62 \pm 8.87$ & $63 \pm 9.29$ & $100 \pm 0.00$ & $100 \pm 0.00$ & $100 \pm 0.00$ & $100 \pm 0.00$ \\
0.25 & $60 \pm 3.65$ & $63 \pm 5.00$ & $100 \pm 0.00$ & $100 \pm 0.00$ & $100 \pm 0.00$ & $100 \pm 0.00$ \\
0.30 & $69 \pm 3.00$ & $74 \pm 3.83$ & $100 \pm 0.00$ & $100 \pm 0.00$ & $100 \pm 0.00$ & $100 \pm 0.00$ \\
Control & 0 & 0 & 0 & 0 & 0 & 0 \\
\hline
\end{tabular}

Note: \% : percentage and S.E. : standard error

Table 2. Larvicidal potency of three oils against laboratory-reared Aedes aegypti larvae after 24- and 48-hour exposure

\begin{tabular}{|c|c|c|c|c|c|c|c|c|c|c|}
\hline \multirow{3}{*}{ Essential oils } & \multicolumn{10}{|c|}{ Period of exposure } \\
\hline & \multicolumn{5}{|c|}{24 hour after exposure } & \multicolumn{5}{|c|}{48 hour after exposure } \\
\hline & $\begin{array}{c}\mathbf{L C}_{25} \\
(\mathbf{p p m})\end{array}$ & $\begin{array}{c}\mathbf{L C}_{50} \\
(\mathbf{p p m})\end{array}$ & $\begin{array}{c}\mathbf{L C}_{90} \\
(\mathbf{p p m})\end{array}$ & Slope \pm S.E. & $\chi^{2}$ & $\begin{array}{c}\mathbf{L C}_{25} \\
(\mathbf{p p m})\end{array}$ & $\begin{array}{c}\mathbf{L C}_{50} \\
(\mathbf{p p m})\end{array}$ & $\begin{array}{c}\mathrm{LC}_{90} \\
\text { (ppm) }\end{array}$ & Slope \pm S.E. & $\chi^{2}$ \\
\hline Rosemary & 0.18 & 0.23 & 0.35 & $6.72 \pm 0.58$ & 50.15 & 0.15 & 0.21 & 0.41 & $4.55 \pm 0.40$ & 71.05 \\
\hline Vanilla & 0.08 & 0.10 & 0.15 & $7.63 \pm 0.81$ & 6.22 & 0.07 & 0.08 & 0.12 & $8.49 \pm 0.75$ & 1.05 \\
\hline Spearmint & 0.11 & 0.12 & 0.16 & $12.74 \pm 1.16$ & 0.17 & 0.10 & 0.12 & 0.15 & $10.56 \pm 1.00$ & 2.57 \\
\hline
\end{tabular}

Note: $\mathrm{LC}_{25}$ : concentration that kills $25 \%$ of mosquito larvae; LC50: concentration that kills $50 \%$ of mosquito larvae; LC 90 : concentration that kills $90 \%$ of mosquito larvae; ppm: parts per million; S.E.: standard error; $\chi 2$ : chi-Square 


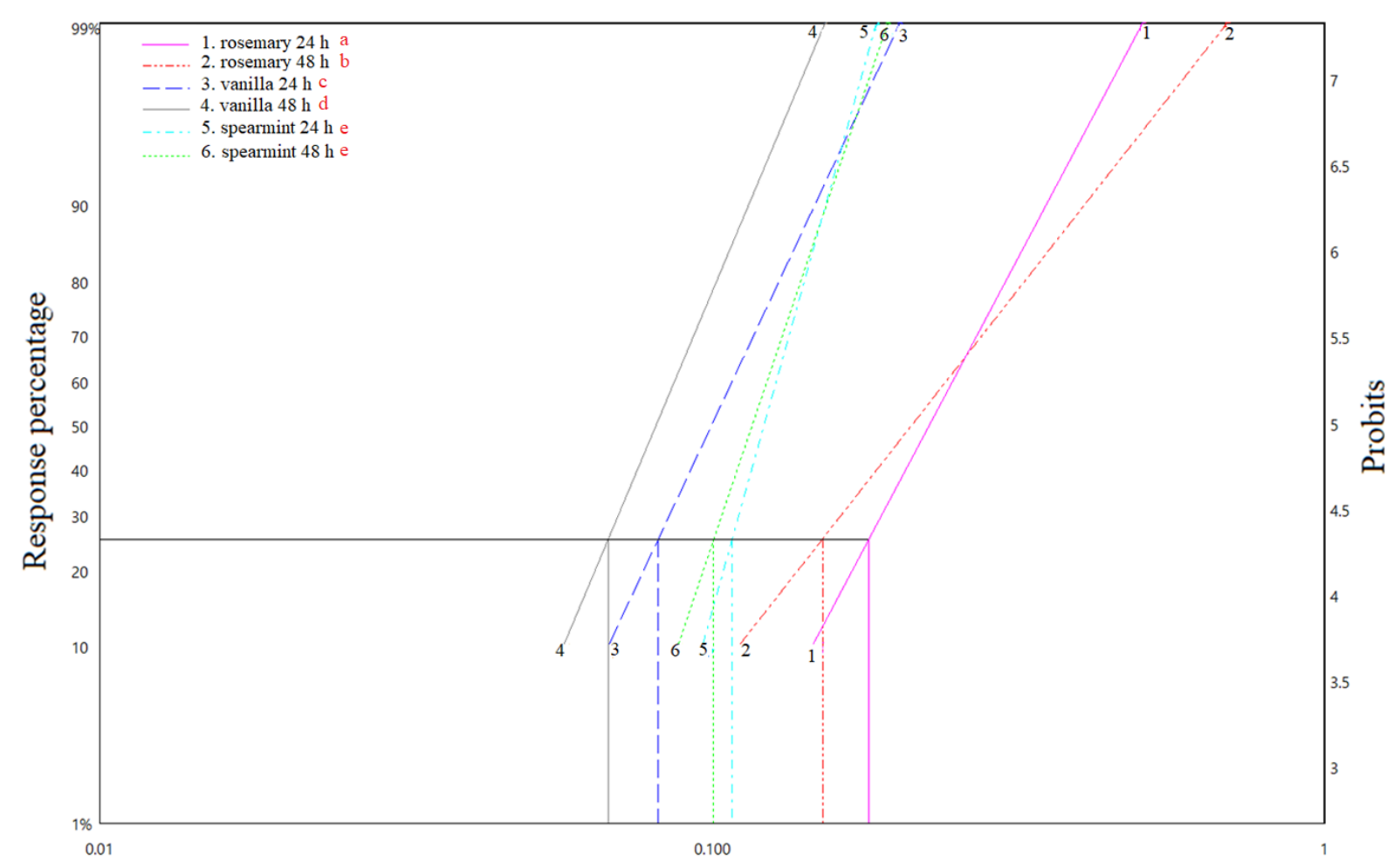

Figure 1. The graph shows the $\mathrm{LC}_{25}$ concentrations for Aedes aegypti larvae at 24 and 48 hours after exposure to commercial rosemary, vanilla, and spearmint essential oils. Significant differences are indicated by different red letters that appear at the end of the descriptions in the upper left corner

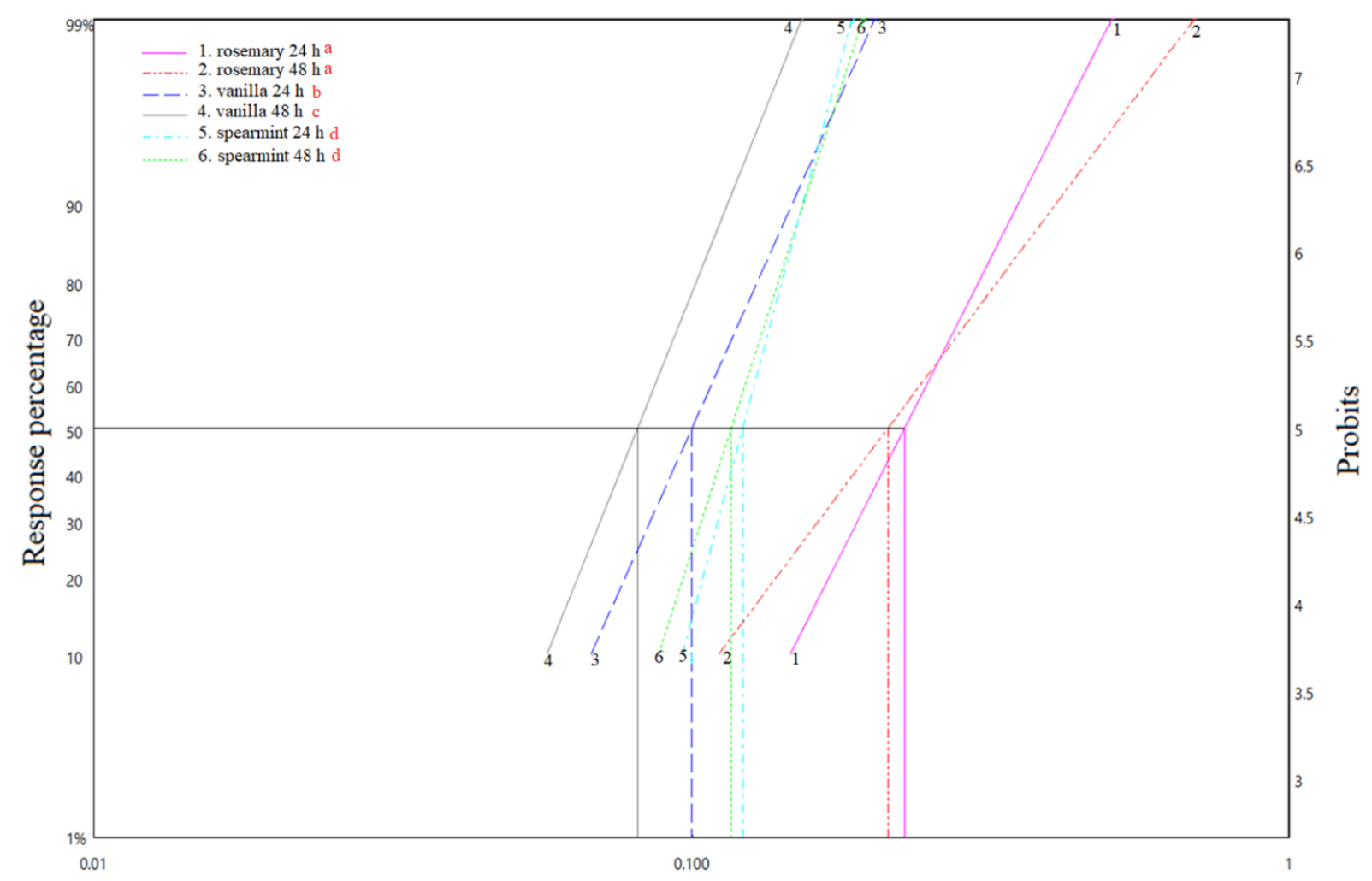

Figure 2. The graph shows $\mathrm{LC}_{50}$ calculations of Aedes aegypti larvae 24 and 48 hours after exposure to commercial rosemary, vanilla, and spearmint essential oils. Significant differences are indicated by different red letters that appear at the end of the descriptions in the upper left corner 


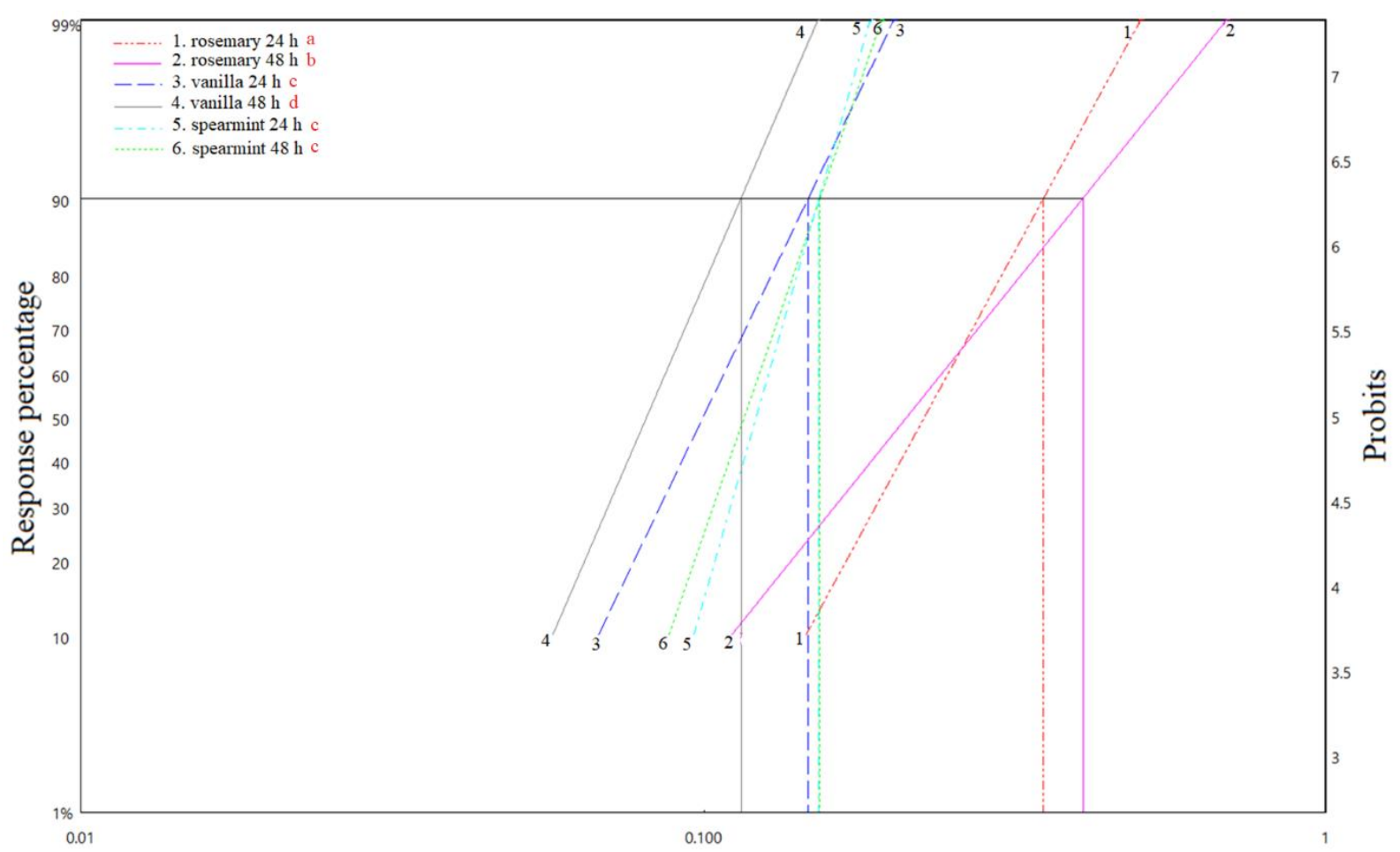

Figure 3. The graph shows the $\mathrm{LC}_{90}$ calculations for Aedes aegypti larvae 24 and 48 hours after exposure to commercial rosemary, vanilla, and spearmint essential oils. Significant differences are indicated by different red letters that appear at the end of the descriptions in the upper left corner

Aedes aegypti mosquito is the main vector of dengue fever, which is a major public health problem throughout the world. Controlling populations of this mosquito is done by destroying larval breeding sites. Natural products are an interesting option because they are not toxic to non-target organisms. The findings of this study demonstrate that commercially available aromatic rosemary, spearmint, andespecially-vanilla essential oils can eliminate Aedes spp. larvae. High-quality commercial essential oil products are readily available, easy to use, and relatively inexpensive. They are highly concentrated and pure. More studies are needed to test these oils in the field to determine whether they can be used effectively for controlling Aedes species in communities.

\section{ACKNOWLEDGEMENTS}

We thank the Suan Sunandha Rajabhat University, Bangkok, Thailand, which facilitated this study.

\section{REFERENCES}

Achee NL, Gould F, Perkins TA, Reiner RC, Morrison AC, Ritchie SA Scott TW. 2015. A critical assessment of vector control for dengue prevention. PLoS Negl Trop Dis 9 (5): e0003655. DOI: 10.1371/journal.pntd.0003655.

Albrieu Llinás G, Seccacini E, Gardenal CN, Licastro S. 2010. Current resistance status to temephos in Aedes aegypti from different regions of Argentina. Mem Inst Oswaldo Cruz 105 (1): 113-116.
Ali B, Al-Wabel NA, Shams S, Ahamad A, Khan SA, Anwar F. 2015. Essential oils used in aromatherapy: A systemic review. Asian Pac J Trop Biomed 5 (8): 601-611.

Andila PS, Hendra IPA, Wardani PK, Tirta IG, Sutomo S, Fardenan D. 2018. The phytochemistry of Cymbopogon winterianus essential oil from Lombok Island, Indonesia and its antifungal activity against phytopathogenic fungi. Nus Biosci 10 (4): 232-239.

Arifiyanto D, Basyuni M, Sumardi A, Putri LAP, Siregar ES, Risnasari I, Syahputra I. 2017. Occurrence and cluster analysis of palm oil (Elaeis guineensis) fruit type using two-dimensional thin-layer chromatography. Biodiversitas 18 (4): 1487-1492.

Baqueiro-Peña I, Guerrero-Beltrán JÁ. 2017. Vanilla (Vanilla planifolia Andr.), its residues and other industrial by-products for recovering high value flavor molecules: A review. J Appl Res Med Aromat Plants 6 (2017): 1-7.

Barrera R, Amador M, Munoz J, Acevedo V. 2018. Integrated vector control of Aedes aegypti mosquitoes around target houses. Parasit Vectors 11 (1): 1-8.

Bilcu M, Grumezescu AM, Oprea AE, Popescu RC, Mogoanu GD, Hristu R, Stanciu GA, Mihailescu DF, Lazar V, Bezirtzoglou E, Chifiriuc MC. 2014. Efficiency of vanilla, patchouli and ylang ylang essential oils stabilized by iron oxide@C14 nanostructures against bacterial adherence and biofilms formed by Staphylococcus aureus and Klebsiella pneumoniae clinical strains. Molecules 19 (11): 1794317956.

Bond JG, Casas-Martínez M, Quiroz-Martínez H, Novelo-Gutiérrez R, Marina CF, Ulloa A, Orozco-Bonilla A, Muñoz M, Williams T. 2014. Diversity of mosquitoes and the aquatic insects associated with their oviposition sites along the Pacific coast of Mexico. Parasit Vectors 7 (41): 1-19.

Bullangpoti V, Mujchariyakul W, Laksanavilat N, Junhirun P. 2018. Acute toxicity of essential oil compounds (thymol and 1,8-cineole) to insectivorous guppy, Poecilia reticulata Peters, 1859. Agric Nat Resour 52 (2): 190-194.

Chaiphongpachara T, Chitsawaeng C, Chansukh KK. 2019. Comparison of the larvicidal and adult mosquito attractant efficacy between straw mushroom Volvariella volvacea extract and octenol (1-octen-3-ol) on 
mosquito vectors (Diptera: Culicidae). J Appl Pharm Sci 9 (07): $095-$ 099.

Chaiphongpachara T, Sumchung K, Bumrungsuk A, Chansukh KK. 2018. Larvicidal and adult mosquito vector attractant activity of Tremella fuciformis Berk mushroom extract on Aedes aegypti (L.) and Culex sitiens Wiedemann (Diptera: Culicidae). J Appl Pharm Sci 8 (09): 007-010.

Chaiphongpachara T, Moolrat L. 2017. Insecticide resistance of temephos on Aedes aegypti as dengue vector in Samut Songkhram, Thailand. Ann Trop Med Public Health 10 (6): 1439-1442

Cheng SS, Chang HT, Chang ST, Tsai KH, Chen WJ. 2003. Bioactivity of selected plant essential oils against the yellow fever mosquito Aedes aegypti larvae. Bioresour Technol 89 (1): 99-102.

De Sousa BA, de Morais SM, Ferreira PAT, Vieira ÍGP, Craveiro AA, dos Santos Fontenelle RO, de Menezes JESA, da Silva FWF, de Sousa HA. 2015. Chemical composition and functional properties of essential oils from mentha species. Ind Crops Prod 76 (12): 557-564.

Derua YA, Rumisha SF, Batengana BM, Max DA, Stanley G, Kisinza WN, Mboera LEG. 2017. Lymphatic filariasis transmission on Mafia Islands, Tanzania: Evidence from xenomonitoring in mosquito vectors. PLoS Negl Trop Dis 11 (10): e0005938. DOI: 10.1371/journal.pntd.0005938

Dhifi W, Bellili S, Jazi S, Bahloul N, Mnif W. 2016. Essential oils' chemical characterization and investigation of some biologica activities: A critical review. Medicines (Basel) 3 (4): E25. DOI: 10.3390/medicines 3040025 .

Dias CN, Moraes DFC. 2014. Essential oils and their compounds as Aedes aegypti L. (Diptera: Culicidae) larvicides: Review. Parasitol Res 113 (2): 565-592

El-Massry KF, Farouk A, Abou-Zeid M. 2008. Free radical scavenging activity and lipoxygenase inhibition of rosemary (Rosmarinus Officinalis L) volatile oil. J Essent Oil-Bearing Plants 11 (5): 536543.

Eskildsen GA, Rovira JR, Smith O, Miller MJ, Bennett KL, McMillan WO, Loaiza J. 2018. Maternal invasion history of Aedes aegypti and Aedes albopictus into the isthmus of Panama: Implications for the control of emergent viral disease agents. PLoS One 13 (3): e0194874. DOI: 10.1371/journal.pone.0194874

Fiume MM, Bergfeld WF, Belsito DV, Hill RA, Klaassen CD, Liebler DC, Marks JG, Shank RC, Slaga TJ, Snyder PW, Gill LJ, Heldreth B 2018. Safety assessment of Rosmarinus officinalis (Rosemary)derived ingredients as used in cosmetics. Intl J Toxicol 37 (3): 12S$50 \mathrm{~S}$.

Flores HA, O’Neill SL. 2018. Controlling vector-borne diseases by releasing modified mosquitoes. Nat Rev Microbiol 16 (8): 508-518.

Francikowski J, Baran B, Cup M, Janiec J, Krzyżowski M. 2019. Commercially available essential oil formulas as repellents against the stored-product pest Alphitobius diaperinus. Insects 10 (4): 1-11.

Geetha RV, Roy A. 2014. Essential oil repellents- A short review. Int J Drug Dev Res 6 (2): 20-27.

George L, Lenhart A, Toledo J, Lazaro A, Han WW, Velayudhan R, Horstick O. 2015. Community-effectiveness of temephos for dengue vector control: A systematic literature review. PLoS Negl Trop Dis 9 (9): e0004006. DOI: 10.1371/journal.pntd.0004006.

Getachew D, Tekie H, Gebre-Michael T, Balkew M, Mesfin A. 2015 Breeding sites of Aedes aegypti: Potential dengue vectors in dire Dawa, east Ethiopia. Interdiscip Perspect Infect Dis 2015: 706276. DOI: $10.1155 / 2015 / 706276$

Goindin D, Delannay C, Gelasse A, Ramdini C, Gaude T, Faucon F, Fouque F. 2017. Levels of insecticide resistance to deltamethrin, malathion, and temephos, and associated mechanisms in Aedes aegypti mosquitoes from the Guadeloupe and Saint Martin islands (French West Indies). Infect Dis Poverty 6 (1): 1-15.

Goubert C, Minard G, Vieira C, Boulesteix M. 2016. Population genetics of the Asian tiger mosquito Aedes albopictus, an invasive vector of human diseases. Heredity 117 (3): 125-134.

Govindarajan M, Benelli G. 2016. Eco-friendly larvicides from Indian plants: Effectiveness of lavandulyl acetate and bicyclogermacrene on malaria, dengue, and Japanese encephalitis mosquito vectors. Ecotoxicol Environ Saf 133: 395-402.

Govindarajan M, Sivakumar R, Rajeswari M, Yogalakshmi K. 2012 Chemical composition and larvicidal activity of essential oil from Mentha spicata (Linn.) against three mosquito species. Parasitol Res 110 (5): 2023-2032.

Grisales N, Poupardin R, Gomez S, Fonseca-Gonzalez I, Ranson H, Lenhart A. 2013. Temephos resistance in Aedes aegypti in Colombia compromises dengue vector control. PLoS Negl Trop Dis 7 (9): e2438. DOI: 10.1371/journal.pntd.0002438

Harbach RE. 2013. Mosquito taxonomic inventory: Anopheles classification. www. mosquito-taxonomic-inventory.info/node/11358.

Hasan S, Jamdar SF, Alalowi M, Al Ageel Al Beaiji SM. 2016. Dengue virus: A global human threat: Review of literature. J Intl Soc Prev Commun Dent 6 (1): 1-6.

Hasani R, Mehregan I, Larijani K, Nejadsattari T, Scalone R. 2017. Survey of the impacts of soil and climatic variations on the production of essential oils in Heracleum persicum. Biodiversitas 18 (1): 365-377.

Hasmiwati RSR, Nofita E. 2018. Detection of ace-1 gene with insecticides resistance in Aedes aegypti populations from DHF-endemic areas in Padang, Indonesia. Biodiversitas 19 (1): 31-36.

Hasmiwati, Supargiyono. 2018. Genotyping of kdr allele in insecticide resistant-Aedes aegypti populations from West Sumatra, Indonesia. Biodiversitas 19 (1): 31-36.

Islam S, Haque CE, Hossain S, Rochon K. 2019. Role of container type, behavioural, and ecological factors in Aedes pupal production in Dhaka, Bangladesh: An application of zero-inflated negative binomial model. Acta Trop 193: 50-59.

Isman MB, Wilson JA, Bradbury R. 2008. Insecticidal activities of commercial rosemary oils (Rosmarinus officinalis) against larvae of Pseudaletia unipuncta and Trichoplusia $n i$ in relation to their chemical compositions. Pharm Biol 46 (1-2): 82-87.

Jayaraj R, Megha P, Sreedev P. 2016. Organochlorine pesticides, their toxic effects on living organisms and their fate in the environment. Interdiscip Toxicol 9 (3-4): 90-100.

Kahamba NF, Limwagu AJ, Mapua SA, Msugupakulya BJ, Msak DS, Kaindoa EW, Okumu FO. 2020. Habitat characteristics and insecticide susceptibility of Aedes aegypti in the Ifakara area, southeastern Tanzania. Parasit Vectors 13 (1): 53

Khani M, Muhamad Awang R, Omar D. 2012. Insecticidal effects of peppermint and black pepper essential oils against rice weevil, Sitophilus oryzae L. and rice moth, Corcyra cephalonica (St.). J Med Plants 11 (43): 97-110.

Koc S, Oz E, Cetin H. 2012. Repellent activities of some Labiatae plant essential oils against the saltmarsh mosquito Ochlerotatus caspius (Pallas, 1771) (Diptera: Culicidae). Parasitol Res 110 (6): 2205-2209.

Komalamisra N, Trongtokit Y, Rongsriyam Y, Apiwathnasorn C. 2005. Screening for larvicidal activity in some Thai plants against four mosquito vector species. Southeast Asian J Trop Med Public Health 36 (6): 1412-1422.

Lee MY. 2018. Essential oils as repellents against arthropods. Biomed Res Intl 2018: 6860271. DOI: 10.1155/2018/6860271.

Mahmoud O, Mohammad MS, Alireza SD, Amir A. 2019. Plant-derived essential oils; their larvicidal properties and potential application for control of mosquito-borne diseases. Galen Medical J 8: e1532. DOI: 10.31661/gmj.v8i0.1532

Morales D, Ponce P, Cevallos V, Espinosa P, Vaca D, Quezada W. 2019. Resistance status of Aedes aegypti to deltamethrin, malathion, and temephos in Ecuador. J Am Mosquito Contr 35 (2): 113-122

Mossa ATH, Mohafrash SMM, Chandrasekaran N. 2018. Safety of natural insecticides: Toxic effects on experimental animals. Biomed Res Intl 2018: 4308054. DOI: 10.1155/2018/4308054.

Ma M, Huang M, Leng P. 2016. Abundance and distribution of immature mosquitoes in urban rivers proximate to their larval habitats. Acta Trop 163: 121-129.

Ndakidemi B, Mtei K, Ndakidemi PA. 2016. Impacts of synthetic and botanical pesticides on beneficial insects. Agric Sci 7 (6): 364-372.

Nerio LS, Olivero-Verbel J, Stashenko E. 2010. Repellent activity of essential oils: A review. Bioresour Technol 101 (1): 372-378.

Nkya TE, Akhouayri I, Kisinza W, David JP. 2013. Impact of environment on mosquito response to pyrethroid insecticides: Facts, evidence and prospects. Insect Biochem Mol Biol 43 (4): 407-416.

Orchard A, Van Vuuren S. 2017. Commercial essential oils as potential antimicrobials to treat skin diseases. Evid-based Compl Altern Med 2017: 4517971. DOI: 10.1155/2017/4517971.

Pavela R. 2015. Acute toxicity and synergistic and antagonistic effects of the aromatic compounds of some essential oils against Culex quinquefasciatus Say larvae. Parasitol Res 114 (10): 3835-3853.

Pavela R. 2015. Essential oils for the development of eco-friendly mosquito larvicides: A review. Ind Crops Prod 76: 174-187.

Pérez-Silva A, Odoux E, Brat P, Ribeyre F, Rodriguez-Jimenes G, Robles-Olvera V, García-Alvarado MA, Günata Z. 2006. GC-MS and GC-olfactometry analysis of aroma compounds in a representative 
organic aroma extract from cured vanilla (Vanilla planifolia G. Jackson) beans. Food Chem 99 (4): 728-735.

Pratiwi R, Anwar C, Novrikasari SH, Ghiffari A, Huda A. 2019. Species diversity and community composition of mosquitoes in a filariasis endemic area in Banyuasin District, South Sumatra, Indonesia. Biodiversitas 20 (2): 453-462.

Rohani A, Azahary ARA, Malinda M, Zurainee MN, Rozilawati H, Najdah WMAW, Lee HL. 2014. Eco-virological survey of Aedes mosquito larvae in selected dengue outbreak areas in Malaysia. J Vector Borne Dis 51 (4): 327-332.

Roiz D, Wilson AL, Scott TW, Fonseca DM, Jourdain F, Müller P, Velayudhan R, Corbel V. 2018. Integrated Aedes management for the control of Aedes-borne diseases. PLoS Negl Trop Dis 12 (12): e0006845. DOI: 10.1371/journal.pntd.0006845.

Sarkic A, Stappen I. 2018. Essential oils and their single compounds in cosmetics-a critical review. Cosmetics 5 (11): 1-21.

Service M. 2008. Medical Entomology for Students, Fourth Edition. Cambridge University Press, United Kingdom.

Souza-Neto JA, Powell JR, Bonizzoni M. 2018. Aedes aegypti vector competence studies: A review. Infect Genet Evol 67: 191-209.

Susilowati D. 2018. Utilization of rosmarin leaf oil (Rosmarinus officinalis L) on Culex quinquefasciatus mosquito larva as a filariasis vector (Elephant foot disease). J Farm 1 (1): 27-33.

Tandina F, Doumbo O, Yaro AS, Traoré SF, Parola P, Robert V. 2018. Mosquitoes (Diptera: Culicidae) and mosquito-borne diseases in Mali, West Africa. Parasit Vectors 11 (467): 1-12.
Tripathi AK, Prajapati V, Aggarwal KK, Kumar S. 2009. Toxicity, feeding deterrence, and effect of activity of 1,8-cineole from Artemisia апnиa on progeny production of Tribolium castanaeum (Coleoptera: Tenebrionidae). J Econ Entomol 94 (4): 979-983.

Tripathi AK, Prajapati V, Kumar S. 2003. Bioactivities of 1-carvone, dcarvone, and dihydrocarvone toward three stored product beetles. J Econ Entomol 96 (5): 1594-1601.

Utami R. 2016. Preservation effect of Javanese turmeric and red ginger essential oils on coated frozen patin fillets. Nusantara Biosci 8 (2): 264-267.

Valle D, Bellinato DF, Viana-Medeiros PF, Lima JBP, Martins JADJ. 2019. Resistance to temephos and deltamethrin in Aedes aegypti from Brazil between 1985 and 2017. Mem Inst Oswaldo Cruz 114: e180544. DOI: 10.1590/0074-02760180544.

Weeratunga P, Rodrigo C, Fernando SD, Rajapakse S. 2017. Controlling Aedes aegypti and Aedes albopictus. Cochrane Database Syst Rev 2017 (8): 012759. DOI: 10.1002/14651858.CD012759.

World Health Organization. 2005. Guidelines for laboratory and field testing of mosquito larvicides. World Health Organization, Geneva. https://apps.who.int/iris/handle/10665/69101.

World Health Organization. 2020. Dengue and Severe Dengue. World Health Organization, Geneva. www.who.int/news-room/factsheets/detail/dengue-and-severe-dengue. 